\title{
Original Antide
}

\section{Investigation of Acid Blue 62 dye adsorption using SBA-15/Polyaniline mesoporous nanocomposite: Kinetic and Thermodynamic study}

\author{
Iman Akbartabar ${ }^{1}$ Mohammad Esmail Yazdanshenas ${ }^{1}$ Habib-Allah Tayebi ${ }^{2}$ Navid Nasirizadeh ${ }^{1}$
}

1. Department of Textile Engineering, Yazd Branch, Islamic Azad University, Yazd, Iran

2. Department of Textile Engineering, Qaemshahr Branch, Islamic Azad University, Qaemshahr, Iran

*Correspondence to: Habib-Allah Tayebi

tayebi_h@yahoo.com

\section{Abstract}

Background and Purpose: This study aimed to investigate the adsorption of Acid Blue 62 (AB62) as an anionic dye from aqueous solution onto as SBA-15/Polyaniline (SBA-15/PAni) mesoporous nanocomposite a low-cost adsorbent and feasible.

Materials and Methods: Fourier transform infra-red spectroscopy (FTIR), Filed Emission Scanning Electron Microscope (FESEM), Transmission Electron Microscope (TEM), X-ray Diffraction (XRD), and BET were used to examine the structural characteristics of obtained adsorbent. The effective parameters on batch adsorption process such as $\mathrm{pH}$, dosage, and time were investigated and optimized. For determining the type of kinetic model, pseudo first order, pseudo second order, Elovich and intra-particle diffusion kinetic models were applied. Thermodynamic parameters such as changes in Gibbs free energy $\left(\Delta \mathrm{G}^{\circ}\right)$, enthalpy $\left(\Delta \mathrm{H}^{\circ}\right)$, and entropy $\left(\Delta S^{\circ}\right)$ were calculated.

Results: Maximum BET specific surface and pore volume on the adsorbent were $224.4 \mathrm{~m}^{2} / \mathrm{g}$ and $0.46 \mathrm{~cm}^{3} / \mathrm{g}$, respectively. The obtained optimized condition was as follows: $\mathrm{pH}=2$, time $=60 \mathrm{~min}$, temperature $25^{\circ} \mathrm{C}$, and adsorbent dose $=0.3 \mathrm{~g} / \mathrm{l}$. The adsorption kinetic data well-fitted by pseudo-second order kinetic equation. The negative values of $\Delta \mathrm{G}^{\circ}$ and $\Delta \mathrm{H}^{\circ}(-4.012 \mathrm{KJ} / \mathrm{mol})$ and the positive value of $\Delta \mathrm{S}^{\circ}(0.409 \mathrm{~J} / \mathrm{mol} \mathrm{K})$ showed that the $\mathrm{AB} 62$ adsorption process was spontaneous, physi-sorption, feasible and exothermic.

Conclusion: SBA-15/PAni can well be used as a low-cost surface adsorbent for removal of AB62 from aqueous media.

Keywords: SBA-15; Acid Blue 62; Polyaniline; Kinetic; Adsorption

Citation: Akbartabar I, Yazdanshenas ME, Tayebi HA*, Nasirizadeh N. Investigation of Acid Blue 62 dye adsorption using SBA-15/Polyaniline mesoporous nanocomposite: Kinetic and Thermodynamic study.2017; 5 (3): $17-34$

Copyright (C) 2017, Published by Mazandaran University of Medical Sciences on behalf of Iranian Journal of Health Sciences and Health Sciences Research Center. This is an open-access article distributed under the terms of the Creative Commons Attribution-Non Commercial 4.0 International License https://creativecommons.org/licenses/by-nc/4.0/which permits copy and redistribute the material just in noncommercial usages, provided the original work is properly cited. 


\section{Introduction}

Dyes are widely used in several sources, such as textiles, printing, dyeing, dyestuff manufacturing,cosmetics, food processing, pharmaceutical, paper, rubber, plastics and leather; and their discharge into water causes environmental pollution (1-3). By development of dyeing process and industries, one of the main sources of pollution, and consequently a common problem for many countries, is dye wastewaters. Dye wastewaters can cause potential mutagenic, high biotoxicity, and carcinogenic effects on the aquatic toxicity and mammals. Plus, they can cause health problems like skin irritation, allergic dermatitis, and cancer in humans. As a result, organic dyes should be removed from wastewater before discharging into water in order to minimize the pollution risks produced by these sewages (1-4)

Some methods have been carried out for dyes removal from dye wastewaters. A wide range of methods containing physical, chemical and biological techniques have been performed to reduce their impact on the environment as well. Although some chemical and biological methods, such as ozonation (6), coagulation (7), flocculation (8), photocatalytic degradation (9), hypochlorite treatment (10), trickling filter (11), activated sludge (12), chemical precipitation (13), physical separation (14), biological degradation aerobic/anaerobic digestion (16), advanced oxidation processes (AOPs) (17), and electrochemical (18) techniques are suitable in removing dyes, they require some special equipment, and are usually energy intensive. In addition, these processes often generate large amounts of byproducts. Among all existing techniques that were studied, it was found that physical processes, such as adsorption, might be an efficient and economic process to remove dyes and control the bio-chemical oxygen demand, as well (1921). Moreover, this method is efficient due to its simplicity, convenience, reversibility and insensitivity to toxic substances. This process helps to transfer the species from the water sewage to a solid phase by maintaining the volume of sewage at a minimum amount (1-3,). To gain this purpose, a large amount of new materials were applied as adsorbents.

Recently, mesoporous structures have attracted researchers as a novel type of adsorbents for removing organic compounds, such as dyes, phenolic compounds $(18,22)$, and heavy metals due to their unique features like the high specific surface and large and tunable pore channels. Common used types of mesoporous silica structures are SBA-1 (23), SBA-3 (24), SBA-15 (25), SBA-16 (26), MCM- 41 (27), MCM-48 (28), and hexagonal mesoporous silica (HMS) (29). The SBA-15, a family of highly arranged mesoporous silica compounds, has attracted the great interest (to be modified and functionalized) due to its large mesopore volume, high surface area, thicker pore walls $(3.1-6.4 \mathrm{~nm})$, high thermal, hydrothermal stability, tailorable large offered pores from 4.6-30 nm, and slim distribution of pore size in comparison to other mesoporous silica structures (30). In addition, it reveals the presence of micropores that are in control into the pore boundaries and also intraconnectivity in the channels of adjacent mesopore by micropores and slim mesopores. This non-stop network helps diffusion into the whole SBA-15 porous 
structure during adsorbing process. Therefore, it is vital to discover SBA-15 designation and modification support for high dyes adsorption capacity, especially higher than room temperature, by functionalization of amine (30). The amine group plays a key role in determining the medicated silica mesoporous adsorbents performance. Various amines have been tested including alkanolamines (31), amine-containing silanes, such as 3-amino propyl trimethoxysilane (32), oligomeric amines, such as polyethyleneimine (PEI) (33) and tetraethylenepentamine (TEPA) (34), and conductive electroactive polymeric compounds, such as polypyrrole (PPy) (35)and polyaniline (PAni) (36).

In the last decade, PAni has gained so much attention for its suitable polymers due to their sufficient electrical conductivity, low-cost monomer, nontoxicity, forming adhesive coating by different substrates, electrochemical properties, and their unique features to hybrid with inorganic mesoporous compounds, as well. Among them, PAnis have been widely provided as adsorbents due to sufficient environmental stability to water and oxygen, simple preparation and high adsorption capacities for important media in removing pollutants from water. This led to an increasing interest in selecting polymeric adsorbents [37-40]. The modification of as-prepared SBA-15 mesoporous with conducting polymers can remarkably increase the adsorption capacity. Although a wide investigation has been carried out about the SBA-15 in the metal ion adsorption (41), there is no systematic study about dyes adsorption by SBA-15 modified with different aminecontaining compounds.

In this study, SBA-15 was synthesized, and then functionalized by polyaniline. The produced material was used as an adsorbent for removal of Acid Blue 62 from aqueous media. The effects of various parameters including adsorbent dose, initial concentration of the aqueous phase, and $\mathrm{pH}$ of the solution were thoroughly studied. Then, the absorption studies of Acid Blue 62, such as isotherms, kinetics, and thermodynamics sorption, were performed on the produced absorbents.

\section{Material and Methods}

\subsection{Materials}

In order to conduct the experiment, Surfactant Pluronic P123 $\left(\mathrm{EO}_{20} \mathrm{PO}_{70} \mathrm{EO}_{20}\right.$, average MW 5800) was purchased from Sigma-Aldrich Corporation. Tetraethyl orthosilicate (TEOS, reagent grade 98\%), hydrochloric acid ( $\mathrm{HCl}, 37 \%)$, and sodium hydroxide (.99.9\%), Hexadecyl Trimethyl Ammonium Bromide (CTAB), acetone, sulfuric acid, and $\mathrm{KIO}_{3}$ were also provided from Merck Corporation. Aniline (ANI, 99\%) was obtained from Merck and was distilled under reduced pressure before use. Acid blue 62 (AB62), an anionic dye, (see Figure 1 and Table 1) were obtained from Dystar. All the above chemicals were used as received without any further purification. 
Table 1.Characteristics of AB62 (42)

\begin{tabular}{cccccc}
\hline Name & CAS number & C.I. number & Formula & Molecular weight & $\lambda$ max \\
\hline Acid Blue 62 & $4368-56-3$ & 62045 & $\mathrm{C}_{20} \mathrm{H}_{19} \mathrm{~N}_{2} \mathrm{NaO}_{5} \mathrm{~S}$ & $422.43 \mathrm{~g} / \mathrm{mol}$ & $620 \mathrm{~nm}$ \\
\hline
\end{tabular}<smiles>Nc1c(S(=O)(=O)O)cc(NC2CCCCC2)c2c1C(=O)c1ccccc1C2=O</smiles>

Figure. 1 Chemical structure of AB62 [42]

\subsection{Preparation and Functionalization of Nan-mesoporous Silica SBA-15}

The mesoporous SBA-15 used in this work was synthesized according to the method proposed by Tayebi et al. (41). Typically, $12.5 \mathrm{ml}$ of P123 as amphiphilic Block copolymer nonionic surfactant of the organic structure directing agent, and 375 $\mathrm{ml}$ of distilled water along with $75 \mathrm{ml}$ of $\mathrm{HCl}$ as the $\mathrm{pH}$ controlling agent were stirred at $42{ }^{\circ} \mathrm{C}$. Then, $31.5 \mathrm{ml}$ of TEOS as the silica source was added to the homogeneous mixture. The obtained gel was placed in static conditions at $42{ }^{\circ} \mathrm{C}$ for $24 \mathrm{~h}$. Next, the hydrothermal temperature was increased to $138{ }^{\circ} \mathrm{C}$ and maintained for $24 \mathrm{~h}$. After filtration, the obtained powder was transferred to a furnace for calcinations at $550{ }^{\circ} \mathrm{C}$ for $5 \mathrm{~h}$ in order to remove the existing organics in its pores.

Surface modifications over nanomesoporous SBA-15 have been performed by post-synthesis grafting method (43). In order to functionalize SBA-15 sorbents, 1 $\mathrm{g}$ of $\mathrm{KIO}_{3}$ was added to $100 \mathrm{~mL}$ sulfuric acid (1 $\mathrm{M})$ and was stirred using magnetic mixer for $10 \mathrm{~min}$ at room temperature. $1 \mathrm{~g}$ of SBA-15 and $0.2 \mathrm{~g}$ of CTAB were added to the solution. Also, after $20 \mathrm{~min}, 1 \mathrm{~mL}$ fresh distilled aniline was added to the stirred solution. The reaction was carried out for $5 \mathrm{~h}$ at room temperature. The product SBA-15/PAni nanocomposite was filtered and rinsed several times with deionized water and acetone, then dried at $60{ }^{\circ} \mathrm{C}$ temperature in an oven for $24 \mathrm{~h}$.

\subsection{Instrumentation}

The surface morphology of the SBA-15 and SBA-15/PAni was observed by the Field emission scanning electron microscopy (FESEM), TESCAN, MIRA3 electron microscope. The nanomeso structures of these materials were characterized by Transmission Electron Microscopy (TEM), Philips, CM/20, Netherlands. $\quad \mathrm{N}_{2}$ adsorption/desorption isotherms of the synthesized samples were carried out on Chem BET 3000 TPR/TDP, USA at $77 \mathrm{~K}$ to determine an average pore diameter. The specific surface area of nanomeso structures was measured by the Brunauer-Emmet-Teller (BET) method. The pore diameters were determined from the adsorption branch according to Barrett-Joyner-Halenda (BJH) method. The total pore volume was estimated from the amount adsorbed at the relative pressure $(\mathrm{P} / \mathrm{P} 0)$. For analyzing the meso 
structures of pristine materials, small-angle $\mathrm{X}$-ray diffraction $(\mathrm{XRD})$ patterns in the range of $0.6<2 \theta<9$ were structurally determined with XPERT-PRO40 $\mathrm{kV}$ spectrometer using $\mathrm{Cu} \mathrm{K \alpha}$ radiation $(\lambda=$ $1.5406 \AA$ ). Fourier transform infra-red (FTIR) spectra resulting for the mesoporous SBA-15 and SBA-15/PAni were investigated with Shimadzu model 4300, Japan. The adsorption of dyes was detected using a UV-visible spectrophotometer Jenway, 6505, UK.

\subsection{Adsorption studies}

All Adsorption experiments were conducted in a closed $250 \mathrm{ml}$ glass pyramid bottle in a shaker at $200 \mathrm{rpm}$. Batch experiments were carried out through contacting different dosage of the SBA-15 and SBA-15/PAni with $100 \mathrm{ml}$ AB62 solution with different initial concentrations various $\mathrm{pH}$ values, temperatures and times. The $\mathrm{pH}$ values of the solution were adjusted in the range of 2-12 using $0.1 \mathrm{~N}$ solutions of $\mathrm{HCl}$ and $\mathrm{NaOH}$. At the end of the process, the adsorbent was separated by centrifuging at $4000 \mathrm{rpm}$ in $20 \mathrm{~min}$. The concentration of AB62 in the solution was measured spectrophotometrically at $620 \mathrm{~nm}$. Each experiment was repeated five times and the experimental results bore average values. The percentage of removal efficiency of AB62 and adsorbed amounts $\mathrm{q}_{\mathrm{t}}(\mathrm{mg} / \mathrm{g})$ were calculated using the following relationships:

$$
\begin{aligned}
& \mathrm{R}=\frac{\left(C_{0}-C_{e}\right)}{C_{0}} \times 100 \\
& q_{t}=\frac{\left(C_{o}-C_{t}\right) V}{W}
\end{aligned}
$$

where $\mathrm{C} 0$ and $\mathrm{Ct}$ represent dye concentrations at initial and different times, respectively $(\mathrm{mg} / \mathrm{L}) . \quad \mathrm{V}$ is the volume of dye bath (L) and $\mathrm{W}$ is the weight of adsorbent $(\mathrm{g})$.

\section{Results}

\subsection{Characterization analyses}

The evaluation of specific area, mean pore size diameter and, especially, pore size distribution of mesoporous materials are the subject of controversy [44]. The $\mathrm{N}_{2}$ adsorption/desorption isotherms of the SBA-15 and SBA15/ PAni along with their B.J.H. pore size distributions are shown in Figure 2 and Table 2. While SBA-15 sample exhibited isotherm of classic type IV IUPAC with a hysteresis loop of type $\mathrm{H} 1$, a steep increase of adsorbed $\mathrm{N}_{2}$ was also observed at relative pressure $\mathrm{P} / \mathrm{P0}=0.6-0.8$, demonstrating the formation of cylindrical pore channel as expected for mesoporous materials (41, 44). This material has also relatively high specific surface area and narrow average pore size distribution centered at $7.8 \mathrm{~nm}$. In the case SBA-15/PAni nanocomposite displays, the type IV isotherm with a hysteresis loop was close to $\mathrm{P} / \mathrm{P} 0=0.5$. At the same time, the inflection point of the isotherm shifted to lower P/P0. Thus, SBA-15/PAni isotherm maintained the typical SBA-15 isotherm shape, but with the PAni contents. In addition, the data reported in Table 2 indicate a decrease in specific surface area, and mesopore volume, and pore size of SBA15/PAni was consistent with the grafting of PAni species on the silica surface at the molecular level, which showed that the polymer well incorporated into the channels of SBA-15 (41, 44-46). 


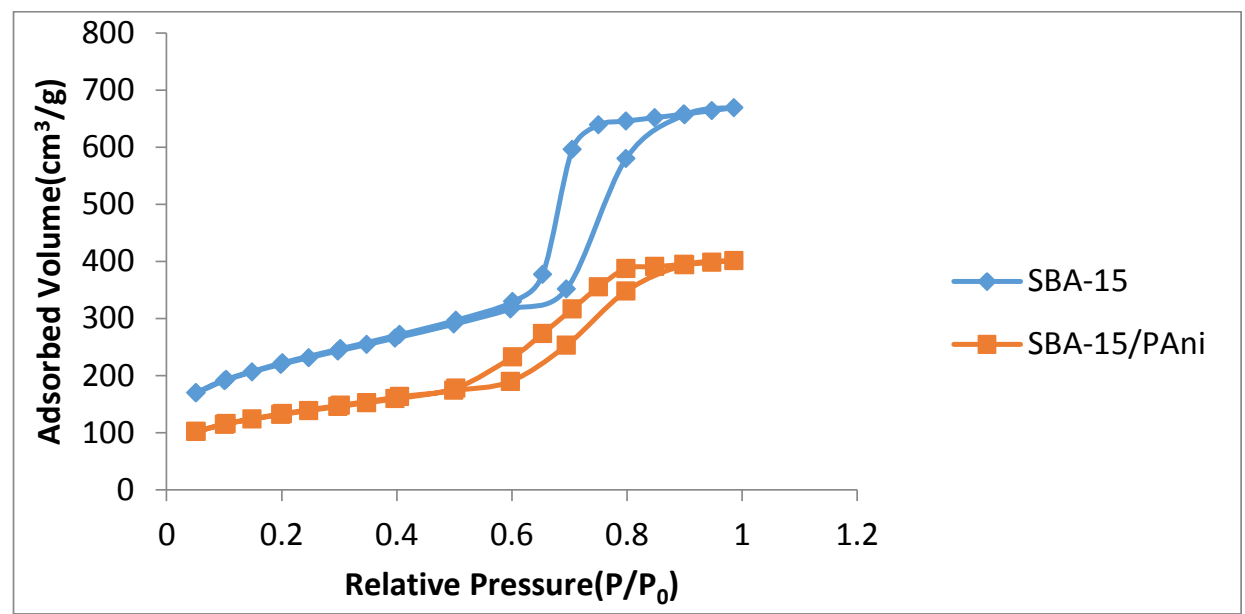

Figure 2. $\mathrm{N}_{2}$ adsorption/desorption isotherms of SBA-15 and SBA-15/PAni.

Table 2 .Structural properties of SBA-15 and SBA-15/PAni.

\begin{tabular}{lccc}
\hline \multicolumn{1}{c}{ Sample } & $\begin{array}{c}\text { Surface area } \\
(\mathbf{B E T})\left(\mathbf{m}^{\mathbf{2}} / \mathbf{g}\right)\end{array}$ & $\begin{array}{c}\text { Pore } \\
\text { diameter } \\
(\mathbf{B J H})(\mathbf{n m})\end{array}$ & $\begin{array}{c}\text { Pore Volume } \\
(\mathbf{B J H})\left(\mathbf{c m}^{\mathbf{3}} / \mathbf{g}\right)\end{array}$ \\
\hline SBA-15 & 748.6 & 7.8 & 0.96 \\
SBA-15/Pani & 224.4 & 4.8 & 0.46 \\
\hline
\end{tabular}

The analysis of the morphology of the synthesized SBA-15 was characterized by TEM, as shown in Figure 3a. The electron beam was radiated parallel to the main axis of the cylindrical pores. The well-ordered hexagonal arrays of pores were also confirmed by the TEM image with high uniformity, and the pore size diameter was evaluated at $7-8 \mathrm{~nm}$, which is close to the

(a)

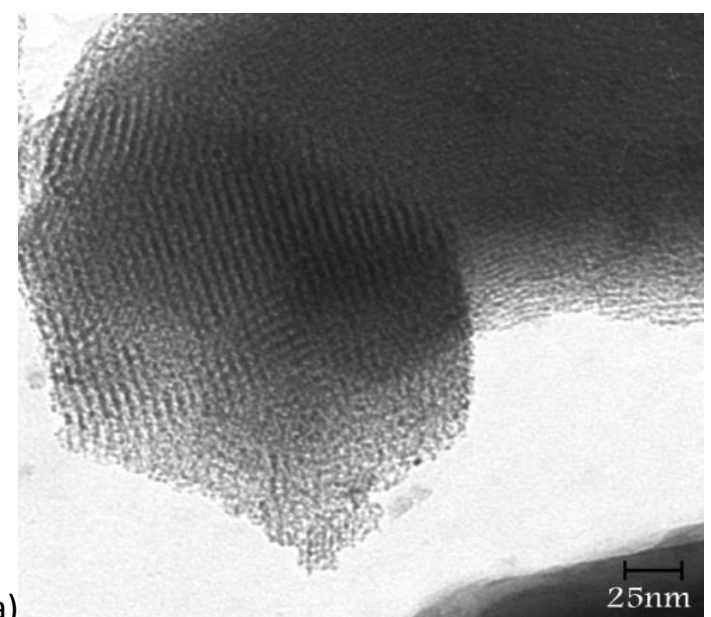

Figure 3. TEM Morphology images of (a) SBA-15 and (b) SBA-15/PAni nanocomposite. pore size calculated by $\mathrm{BJH}$ measurement method (41, 45). After being modified with PAni, the hexagonal meso-structure could be well retained (Fig. 3b), which suggested that the surface modification did not obviously destroy the mesostructure. The obtained results were consistent with corresponding $\mathrm{N}_{2}$ sorption results, as shown in Figure 2.

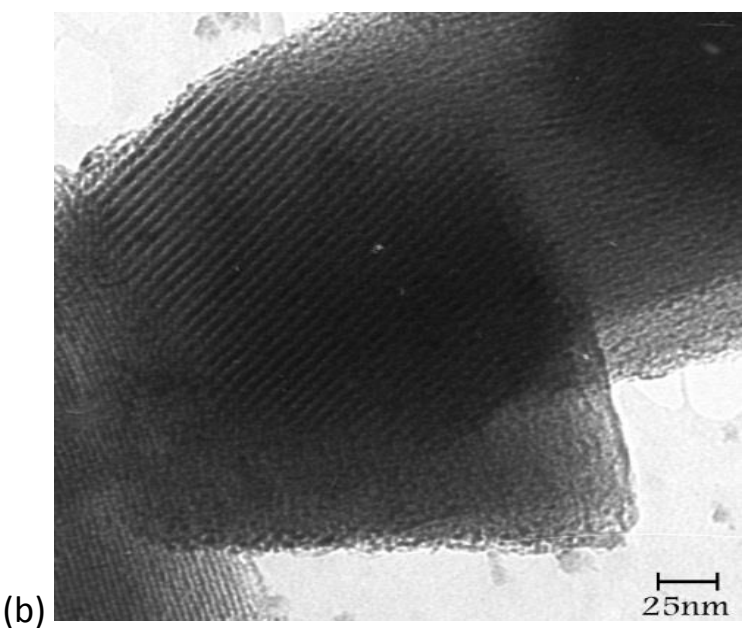

$\stackrel{5 n m}{1}$ 
As illustrated in Figure 4, the FESEM image also revealed that SBA-15 and SBA-15/PAni nanocomposite were an almost hexagonal pillar with a relatively uniform size. In addition, particulates polymerization agglomerates have shown some pores on the outer and inner surface SBA-15, indicating assembly of tiny particle PAni. These results further illustrate that PAni has been successfully fixed on the pore wall of SBA-15 by this modification method.
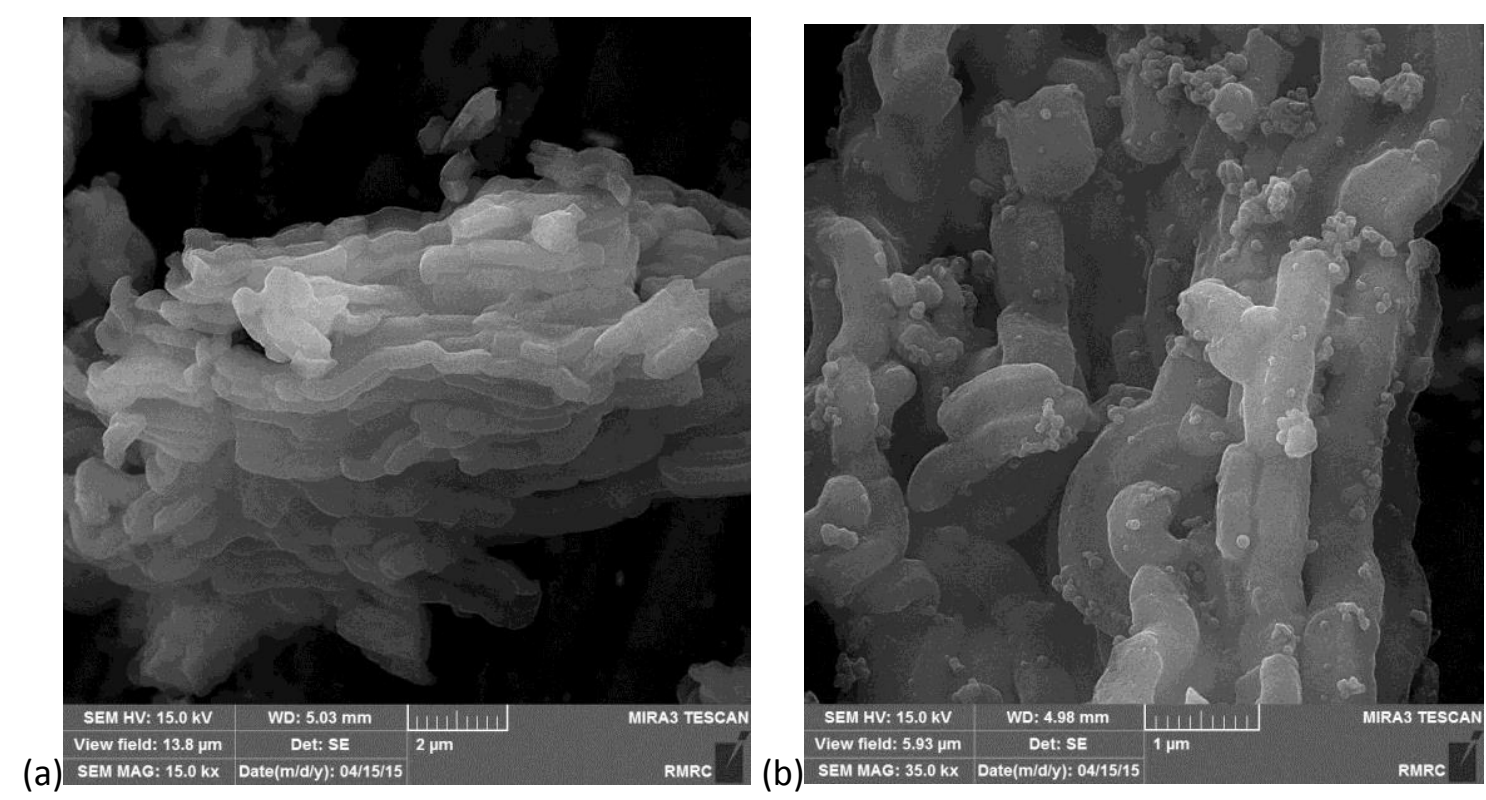

Figure 4. FESEM Morphology images of (a) SBA-15 and (b) SBA-15/PAni nanocomposite.

well-ordered silicate mesoporous structure with P6 mm hexagonal symmetry (47). A small shift toward the larger diffraction angles in our case, as compared to the literature, may be attributed to the difference in the synthesis techniques and calcinations temperature (47-49).
XRD patterns of synthesized SBA-15 and SBA-15/PAni samples (Figure 5) showed that three well-resolved diffraction peaks have been indexed, where the single strong peak $\left(\begin{array}{ll}10 & 0\end{array}\right)$ at $2 \theta=0.95^{\circ}$ corresponding $\mathrm{d}$ spacing was $8.9 \mathrm{~nm}$, and two weak peaks were $(110)$ and $\left(\begin{array}{lll}2 & 0 & 0\end{array}\right)$ at $2 \theta=1.59 \circ$ and $1.81^{\circ}$, respectively, which represented a

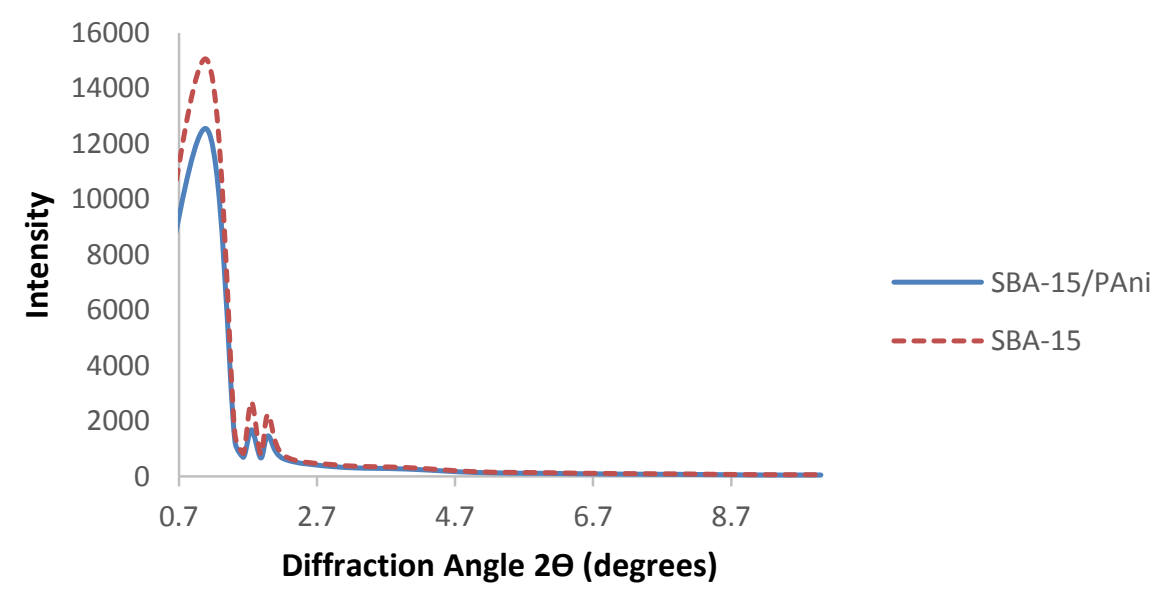

Figure 5. XRD patterns of SBA-15 and SBA-15/PAni. 
As shown in Figure 5, the ordered mesostructure of the SBA-15/PAni nanocomposite was well maintained after PAni modification, indicating that the structure of materials remained unaltered after grafting amine function group. However, the observed meaningful reduction of peak intensities for SBA15/PAni could be relevant to filling the channels of SBA-15 pores by PAni Polymers. Further, XRD pattern included thickness of silica walls, because the approximate pore size of SBA-15 computed by the BJH method, $7.8 \mathrm{~nm}$, was smaller than the $\mathrm{d}$ spacing $8.9 \mathrm{~nm}$ for peak (10 0) of XRD pattern $(41,45)$.

The FTIR spectroscopy provided important information regarding the formation of SBA-15/PAni nanocomposite. The FTIR spectra, analysis of SBA-15, and SBA-15/PAni nanocomposite are all shown in Figure 6, confirming the formation of SBA-15 owing to the presence of the characteristic peaks of silicate materials. The bands 788 and $1099 \mathrm{~cm}^{-1}$ belong to the symmetrical vibrations and asymmetric of bond $\mathrm{Si}-\mathrm{O}-\mathrm{Si}$ bending of $\mathrm{SiO}_{4}$ skeleton. The peaks at 466, 935 and $3434 \mathrm{~cm}^{-1}$ are attributed to the torsion vibration of the bond $\mathrm{Si}-\mathrm{O}-\mathrm{Si}$ and the vibration of the $\mathrm{Si}-\mathrm{OH}$ group, respectively. The appearances of characteristic peaks show the presence of $\mathrm{Si}-\mathrm{OH}$ groups on the silica pore wall. After surface modification, some new peaks and some invisible peaks could be observed on the FTIR spectrum of SBA-15/PAni (Figure 6b), with an exception of the characteristic peaks involved with SBA-15 silica, indicating incorporation of PAni polymer chains with SBA-15 materials $(41,47)$.

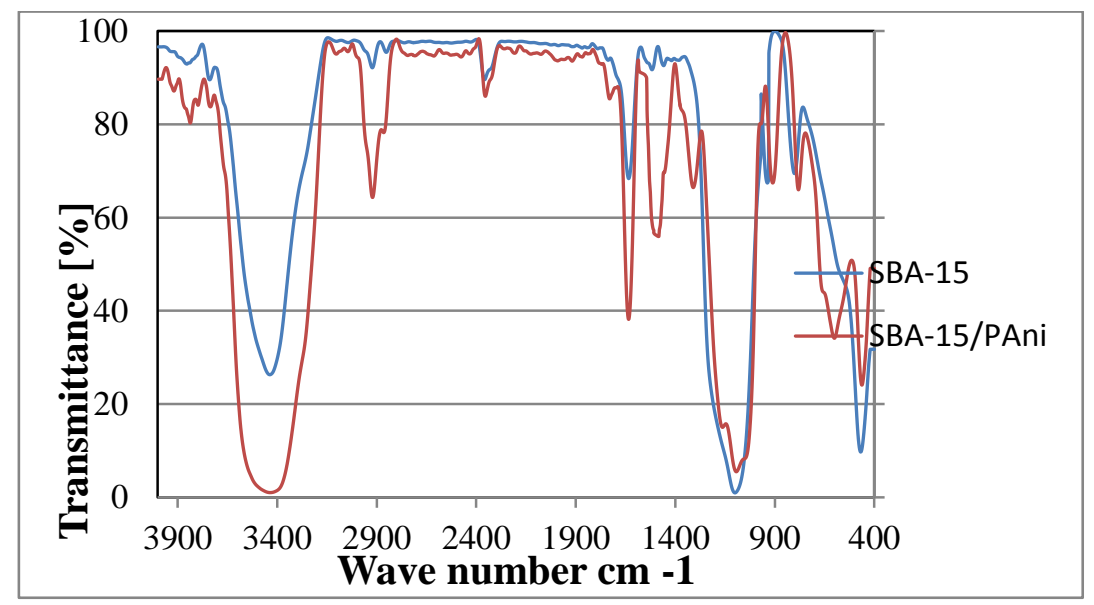

Figure 6. FTIR spectra of SBA-15 and SBA-15/PAni.

The main characteristic peaks for SBA15/PAni are assigned as follows: the peak at $1307 \mathrm{~cm}^{-1}$ can be attributed to $\mathrm{C}-\mathrm{N}$ stretching vibration. The bands related with quinoid and phenyl stretching ring deformations were assigned at 1567 and $1490 \mathrm{~cm}^{-1}$, respectively. In addition, the stretching bands at $1137 \mathrm{~cm}^{-1}$ belonged to $\mathrm{N}$ Q N (Q denotes the quinoid rings), indicating that the reaction between the $\mathrm{OH}$ groups of the silica network with the ethoxy groups of the organic precursor had taken place. These results demonstrate that PAni was successfully functionalized on the pore wall of SBA-15 [41, 45, 47, 50], which further confirmed the results of BET, FESEM, TEM and XRD measurements. 


\subsection{Adsorption studies}

\subsubsection{Effect of $\mathrm{pH}$}

The $\mathrm{pH}$ value of the solution is an important factor that controls the dye adsorption process from aqueous solution onto adsorbent surface active sites (41). The $\mathrm{pH}$ values influence the surface charge of adsorbent during adsorption. Therefore, the dye adsorption capacity was studied by varying $\mathrm{pH}$ ranging from 2 to 12 , while other parameters, such as the amount of adsorbent, concentration of dye, time and temperature, remained constant. The experiment was performed on SBA-15 and SBA-15/PAni nanocomposite with an initial concentration of $40 \mathrm{mg} / \mathrm{L}$, and the amount of adsorbent $0.02 \mathrm{~g}$ at room temperature with contact time of $120 \mathrm{~min}$. The effect of $\mathrm{pH}$ changes on removal efficiency of AB62 is shown in Figure 7. It can be seen that the highest adsorption Value of AB62 was obtained at $\mathrm{pH} 2$. According to Figure 7, the dye adsorption increased with a decrease in $\mathrm{pH}$ level, and an optimum value was reached at an equilibrium $\mathrm{pH}$ of around 2 and removal efficiency of $55.2 \%$. At low $\mathrm{pH}$ values, it may lead to protonation of adsorbent surface (41), because for adsorption of anionic dye (AB62) by the adsorbent, the adsorbent must have a positive charge. In acidic environments, the amino groups of Polymer PAni $\left(-\mathrm{NH}_{2}\right)$ are protonated in the presence of the released $\mathrm{H}^{+}$Protons; therefore, in the current research, with protonation of the adsorption surface, the tendency of AB62 to the adsorption surface increased $(41,43)$.

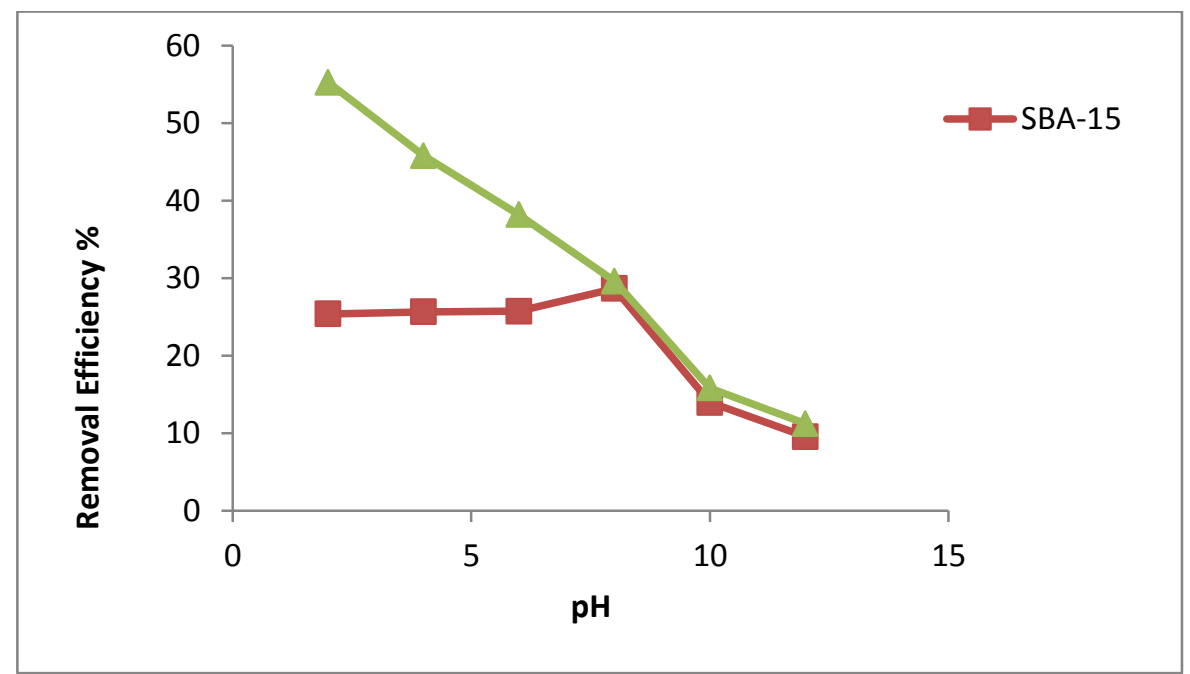

Figure 7. Effect of $\mathrm{pH}$ on the removal efficiency with SBA-15/PAni and SBA-15(initial concentration $=40$ $\mathrm{mg} / \mathrm{L}$, contact time $=120 \mathrm{~min}$, adsorbent dosage $=0.2 \mathrm{~g} / \mathrm{L})$.

As was observed in the present study, in comparison with the adsorption of SBA-15 and SBA-15/PAni, SBA-15/PAni nanocomposite adsorbed more dye, because pure silica surface does not provide strong adsorption sites to interact strongly with acid dyes due to the fact that the hydroxyl groups on the silica surface fail to induce strong interactions with acid dyes (3). The adsorption capacity of mesoporous silica was enhanced through functionalization with amine groups. Actually, the higher adsorption capacity of SBA-15/PAni may be caused by processing via electrostatic interaction and hydrogen bond formation between the surface of the adsorbent and acid dyes [3].

\subsubsection{Effect of adsorbent dosage}

Adsorbent dose is an important parameter in determining the adsorption capacity and 
removal efficiency. The effect of adsorbent amount (SBA-15 and SBA-15/PAni) on the adsorption of acid dye was investigated ranging from 0.02 to $0.10 \mathrm{~g}$ at $\mathrm{pH} 2$ and $100 \mathrm{ml}$ solution of $40 \mathrm{mg} / \mathrm{l} \mathrm{AB62.} \mathrm{The}$ obtained results are presented in Figure 8. By increasing adsorbent dosage to $0.1 \mathrm{~g}$, removal efficiency would enhance adsorbing sites on the adsorbents as expected. At $0.1 \mathrm{~g}$ value, the maximum efficiency was about $77.67 \%$. However, the increase of adsorbent dose to more than $0.03 \mathrm{~g}$ did not affect removal efficiency, which can probably be attributed to the aggregation of adsorbent particles, the documented decrease in surface area, and the availability of less adsorption sites $(3,43)$. Moreover, the high adsorbent dosage might have influenced the physical characteristics of the solid-liquid suspensions by factors, such as increasing the viscosity and inhibiting the diffusion of dye molecules to the surface of the adsorbent (51). Therefore, $0.3 \mathrm{~g} / \mathrm{l}$ of nanocomposite was demonstrated as the optimum adsorbent quantity to AB62 removal in this study.

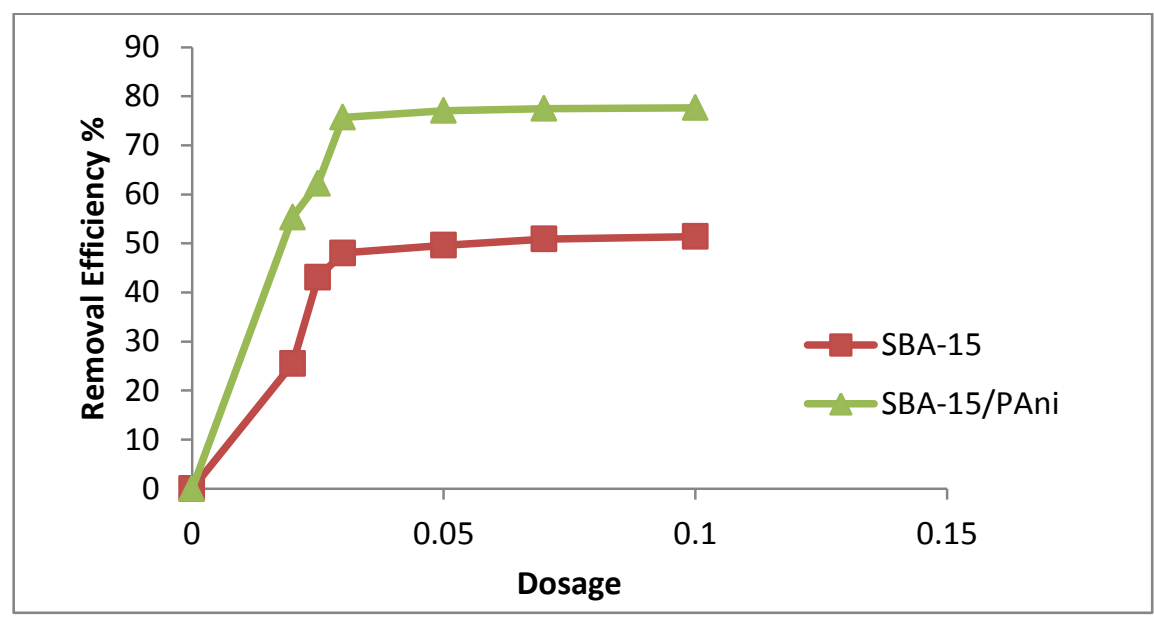

Figure 8. Effect of adsorbent dosage on the removal efficiency with SBA-15/PAni and SBA-15(initial concentration $=40 \mathrm{mg} / \mathrm{L}$, contact time $=120 \mathrm{~min}, \mathrm{pH}=2$ ).

\subsubsection{Effect of contact time and temperature}

Determining the equilibrium time is one of the most important characteristics which represent the adsorption of dye on adsorbent. According to Figure 9, the Adsorption of AB62 by SBA-15/PAni adsorbent for different periods of contact time (5-120 $\mathrm{min})$ and temperatures $(25,35$ and $45{ }^{\circ} \mathrm{C}$ ) was investigated. The initial dye concentration $40 \mathrm{mg} / \mathrm{L}, \mathrm{pH} 2$, and adsorbent dose of $0.03 \mathrm{~g}$ in $100 \mathrm{~mL}$ were used. It was observed that at the initial stage of adsorption (until $15 \mathrm{~min}$ ), AB62 removal had a faster rate due to more active sites accessibility, and then gradually continued at a slower rate until the equilibrium was achieved at $60 \mathrm{~min}$, when adsorption sites became filled out. This meant the longer time had no influence on dye adsorption. Therefore, the optimum contact time of $60 \mathrm{~min}$ was chosen for the next experiments. 


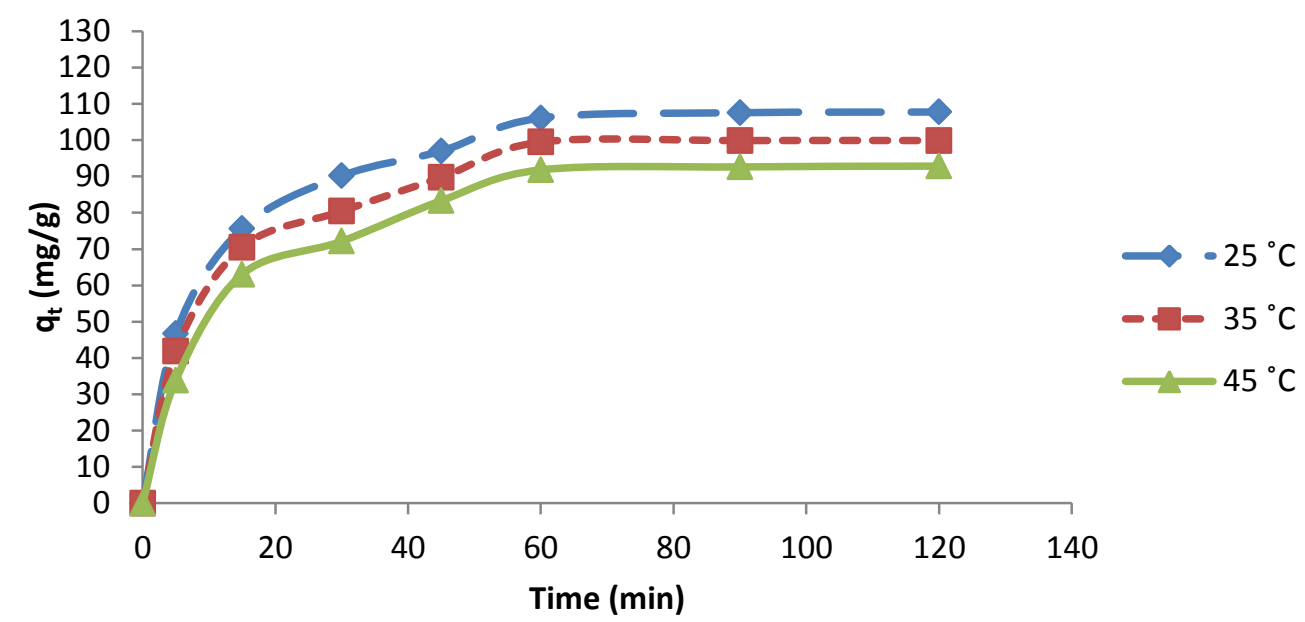

Figure 9. Effect of contact time and temperature on the amount of AB62 dye adsorption on SBA-15/PAni (initial concentration $=40 \mathrm{mg} / \mathrm{L}$, adsorbent dosage $=0.3 \mathrm{~g} / \mathrm{L}, \mathrm{pH}=2$ ).

As shown in Figure 9, the amount of adsorbate per unit mass of adsorbent at time $\mathrm{t},\left(q_{\mathrm{t}},\right)$ was decreased through an increase in temperature from 25 to $45{ }^{\circ} \mathrm{C}$. Therefore, the adsorption process of $\mathrm{AB} 62$ on SBA-15/PAni nanocomposite was exothermic.

\subsection{Adsorption kinetics}

Adsorption kinetics, indicating the absorption rate, is an important characteristic of adsorbents. Finding a controlling mechanism is predominately a limiting-step in adsorption process, such as mass transfer and chemical reaction (52). Different kinetic models have been used to evaluate experimental data. In this part, for the purpose of investigating the kinetics of the process of $\mathrm{AB} 62$ adsorption on SBA15/PAni nanocomposite, four kinetic models including pseudo-first-order, pseudo-second-order, intra-particle diffusion equation and Elovich Model were used. Commonly, pseudo-first and pseudo-second linear kinetic models, as stated by equations 3 and 4, respectively, were used to fit the kinetic data:

$\ln \left(q_{\mathrm{e}}-q_{\mathrm{t}}\right)=\ln q_{\mathrm{e}}-\mathrm{tk}_{1}$

$\frac{t}{q_{\mathrm{t}}}=\frac{1}{k_{2} q_{\mathrm{e}}^{2}}+\frac{\mathrm{t}}{q_{\mathrm{e}}}$

where $\mathrm{k}_{1}$ and $\mathrm{k}_{2}$ were pseudo-first order and pseudo-second order rate constants, respectively; $q_{\mathrm{e}}$ and $q_{\mathrm{t}}$ was the amount of adsorbate per unit of adsorbent at equilibrium and at time $\mathrm{t}(\mathrm{mg} / \mathrm{g})$, respectively. Rate constants and equilibrium adsorption capacities for pseudo-first-order and pseudo-secondorder were estimated from plotted $\ln \left(\mathrm{q}_{\mathrm{e}^{-}}\right.$ $\mathrm{q}_{\mathrm{t}}$ ) versus $\mathrm{t}$ (Figure 10), and plotted $\mathrm{t} / \mathrm{q}_{\mathrm{t}}$ versus $t$ (Figure 11), respectively. The corresponding values are reported in Table 3. Moreover, the high value of correlation coefficient showed that this model could be used to describe adsorption kinetics. 


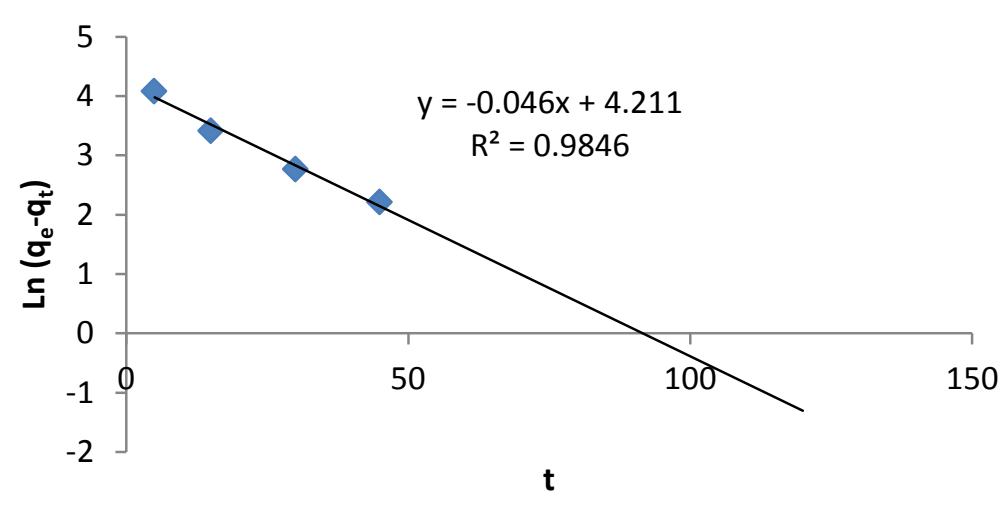

Figure 10. Pseudo-first-order adsorption kinetic for the adsorption AB62 onto SBA-15/PAni.

In order to gain insight into the mechanisms and rate controlling steps affecting the kinetics of adsorption, the kinetic experimental results were found to the intra-particle diffusion (53). The rate of limiting-step can be single or a combination of diffusion steps. Common to the most adsorption processes was that the uptake varied almost proportionally with $\mathrm{t}^{1 / 2}$, the Weber-Morris plot, rather than with the contact time, $\mathrm{t}$ (54), whose model is expressed as:

$q_{\mathrm{t}=K_{\mathrm{id}}} t^{1 / 2}+\mathrm{C}$

where $\mathrm{C}$ is the intercept and $K_{\mathrm{id}}$ is the intra-particle diffusion rate constant, $\left(\mathrm{mg} / \mathrm{gmin}^{1 / 2}\right)$, which can be evaluated from the slope of the linear plot of $q_{t}$ versus $t^{(1 / 2)}$ as shown in Figure 12, for predicting the rate limiting-step. It can be seen from Figure 12 that the adsorption of AB62 consisted of a few linear plots. Because of the boundary layer diffusion and deviation from the center, the first part of the plot indicated boundary layer thickness. Then, at the second part of the plot, the adsorption reduction was attributed to the intra-particle diffusion mechanism (52, 53). This indicated that the intraparticle diffusion was not only a rate controlling step. For intra-particle diffusion model, the estimated values of rate constant $K_{\text {id }}$ and $\mathrm{R}^{2}$ by data regression were 6.656 and 0.828 , respectively.

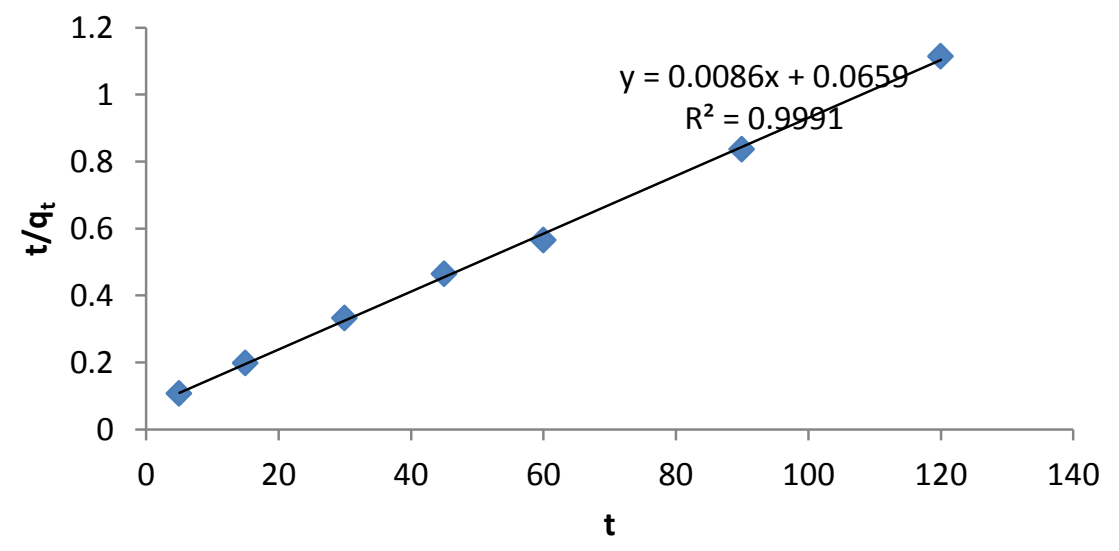

Figure 11. Pseudo-second-order adsorption kinetic for the adsorption AB62 onto SBA-15/PAni. 
One of the most useful models for describing such an activated chemical adsorption was the Elovich Model kinetic, which is expressed as follows:

$q_{\mathrm{t}}=1 / \beta \ln (\alpha \beta)+1 / \beta \operatorname{lnt}$

where $q_{t}$ is the adsorption capacity at time $t$ $(\mathrm{mg} / \mathrm{g}), \alpha$ is the initial adsorption rate $(\mathrm{mg}$ /gmin), and $\beta$ is the desorption constant (gm /g) during each experiment. Thus, the constants can be obtained from the slope and the intercept of a straight line plot of $q t$ against $\ln (t)$. Figure 13 shows Elovich Model curve, in which the adsorption rate increased with high $\alpha$ value and low $\beta$ value.

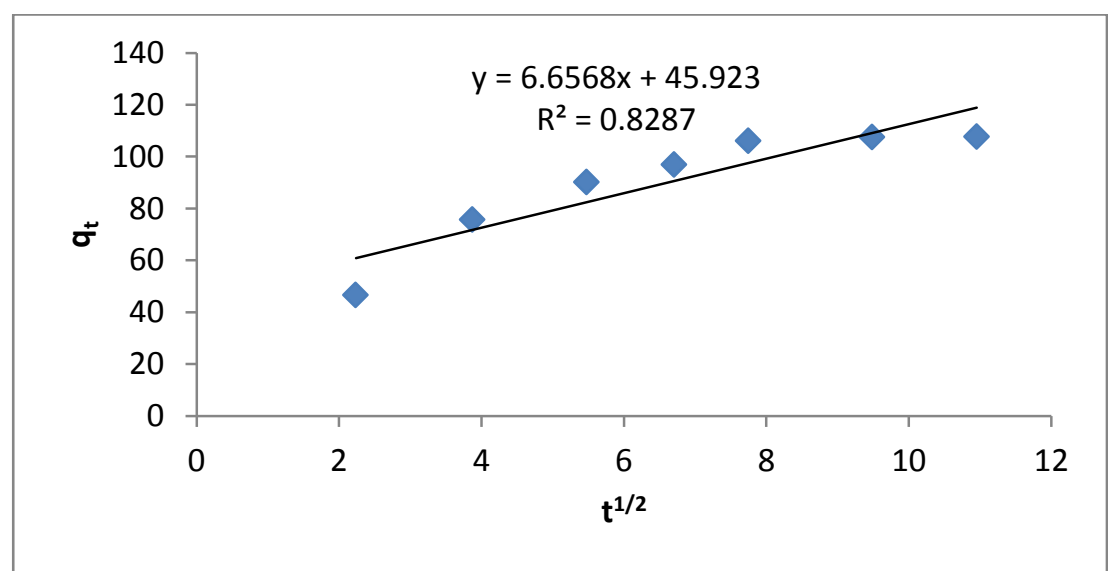

Figure 12. Intra-particle diffusion adsorption kinetic for the adsorption AB62 onto SBA-15/PAni.

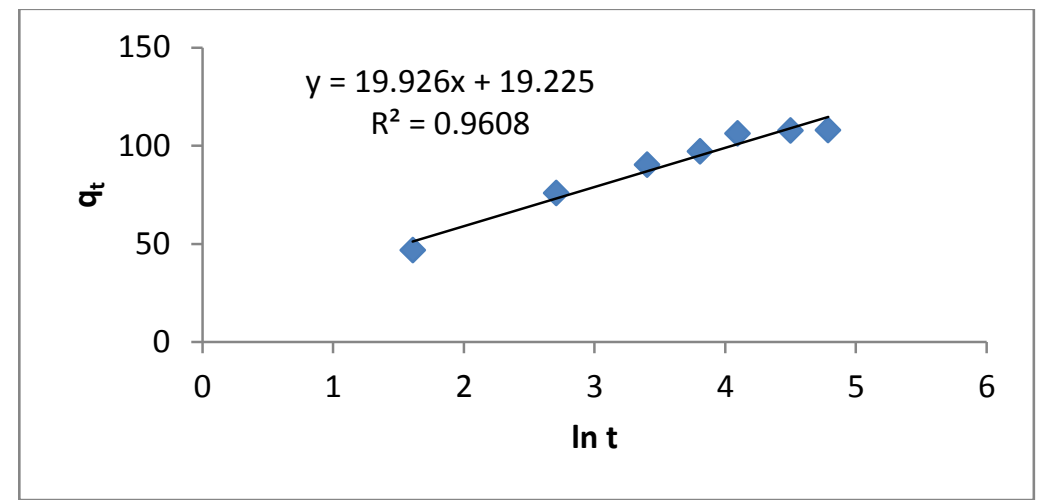

Figure 13. Elovich adsorption kinetic for the adsorption AB62 onto SBA-15/PAni.

The correlation coefficients $\left(\mathrm{R}^{2}\right)$ for the four kinetics models are shown in Table 3. The calculated correlation coefficients are closer to unity for pseudo-second- order kinetics model than the other kinetics models. Therefore, it can be concluded that the adsorption kinetic of AB62 on SBA15/PAni fitted to the pseudo-second-order. 
Table 3. Kinetic parameters for the adsorption of AB62 onto SBA-15/PAni.

\begin{tabular}{cccc}
\hline Pseudo-first-order & $\mathrm{K}_{\mathbf{1}}\left(\mathbf{m i n}^{-1}\right)$ & $\mathbf{q}_{\mathbf{e}}(\mathbf{m g} / \mathrm{g})$ & $\mathbf{R}^{2}$ \\
\hline \multirow{2}{*}{ Pseudo-second-order } & 0.046 & 67.424 & 0.984 \\
& $\mathrm{~K}_{2}\left(\mathrm{~min}^{-1}\right)$ & $\mathrm{q}_{\mathrm{e}}(\mathrm{mg} / \mathrm{g})$ & $\mathrm{R}^{2}$ \\
\multirow{2}{*}{ Intraparticle diffusion } & 0.000985 & 125 & 0.999 \\
& \multicolumn{2}{c}{$\mathrm{K}_{\mathrm{id}}(\mathrm{mg} / \mathrm{g} \mathrm{min})$} & $\mathrm{R}^{2}$ \\
Elovich & \multicolumn{2}{c}{6.656} & 0.828 \\
& $\alpha(\mathrm{mg} / \mathrm{g} \mathrm{min})$ & $\beta(\mathrm{mg} / \mathrm{g})$ & $\mathrm{R}^{2}$ \\
& 52.279 & 0.050 & 0.96 \\
\hline
\end{tabular}

\subsection{Adsorption thermodynamics}

In the current research, thermodynamic analysis was applied to understand the inherent energetic changes associated and the mechanism of adsorption process. To better estimate the effect of temperature on the adsorption of AB62 onto the SBA-15/PAni and to predict thermodynamic behavior of adsorption process, Gibbs free energy $\left(\Delta \mathrm{G}^{\circ}\right)$, enthalpy $\left(\Delta \mathrm{H}^{\circ}\right)$, and entropy $\left(\Delta \mathrm{S}^{\circ}\right)$ values were calculated from equations 7 and 8 :

$\Delta G=-R T \ln K_{\mathrm{d}}$

$\ln K=\frac{\Delta S}{R}-\frac{\Delta \mathrm{H}}{R T}$

where $\mathrm{K}_{\mathrm{d}}$ is the partition ratio, $\Delta \mathrm{H}(\mathrm{J} / \mathrm{mol})$ and $\Delta \mathrm{S}(\mathrm{J} / \mathrm{mol} . \mathrm{K})$ are predicted from slope and intercept of data plotting of $\ln \left(\mathrm{K}_{\mathrm{d}}\right)$ versus $1 / \mathrm{T}$, as shown in Figure 14.

Table 4. Thermodynamic parameters for the adsorption of AB62 onto SBA-15/PAni.

\begin{tabular}{cccccc}
\hline $\mathbf{T}\left({ }^{\circ} \mathbf{C}\right)$ & $\mathbf{K}_{\mathbf{d}}(\mathbf{L} / \mathbf{m o l})$ & $\Delta \mathbf{G}^{\circ}(\mathbf{k j} / \mathbf{m o l})$ & $\Delta \mathbf{H}^{\circ}(\mathbf{k J} / \mathbf{m o l})$ & $\Delta \mathbf{S}^{\circ}(\mathbf{J} / \mathbf{m o l ~ K})$ & $\mathbf{R}^{2}$ \\
\hline $\mathbf{2 9 8}$ & 4.805 & -3.889 & -4.012 & 0.409 & 0.9997 \\
$\mathbf{3 0 8}$ & 4.566 & -3.888 & & & \\
$\mathbf{3 1 8}$ & 4.340 & -3.881 & & & \\
\hline
\end{tabular}

The thermodynamic parameters in this study are reported in Table 4 . The negative $\Delta \mathrm{G}^{\circ}$ values confirmed the spontaneous and thermodynamically favorable nature of AB62 adsorption. Also, the $\Delta \mathrm{G}^{\circ}$ values were in the range of -20 to $0 \mathrm{~kJ} / \mathrm{mol}$, which indicated AB62 adsorption was a physisorption process (54). Moreover, the negative value of $\Delta \mathrm{H}^{\circ}$ for the adsorption process of AB62 represented its exothermic nature. Thus, a higher adsorption capacity was achieved at lower temperature (54). Hence, the positive value of $\Delta \mathrm{S}^{\circ}$ indicated the reversible adsorption of AB62 with SBA-15/PAni nanocomposite. 


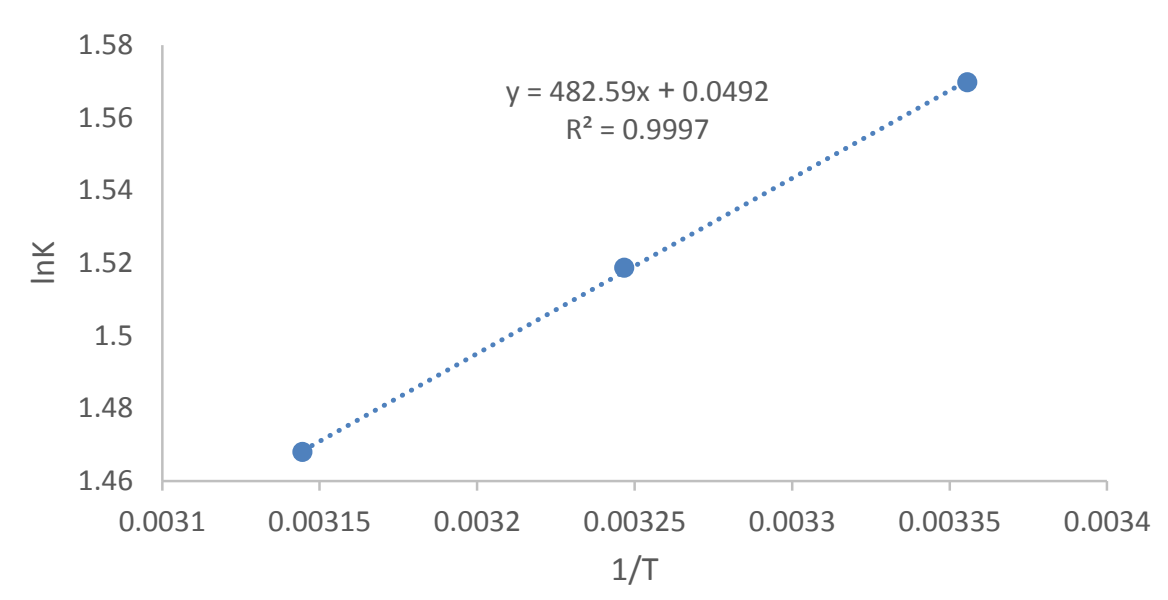

Figure 14. Van't Hoff Regression for the adsorption AB62 onto SBA-15/PAni.

\section{Conclusion}

In this research, SBA-15/PAni mesoporous nanocomposite was synthesized. The results of $\mathrm{N}_{2}$ adsorption/desorption and TEM images illustrated the formation of cylindrical pores and a well-ordered hexagonal array of SBA-15 with high specific area and average pore size of 7- 8 $\mathrm{nm}$. Moreover, the results of FTIR, XRD, TEM, FESEM and $\mathrm{N}_{2}$ adsorption/desorption, indicated successful functionalization of PAni on pore wall of SBA-15. The SBA-15/PAni nanocomposite is an effective adsorbent for the removal of AB62 dye from water. The maximum removal efficiency of AB62 dye was observed to be at a sorbent dose of $0.03 \mathrm{~g}$, contact time of $60 \mathrm{~min}$, temperature of $25{ }^{\circ} \mathrm{C}$, and $\mathrm{pH}=2$. The results of adsorption kinetic revealed that AB62 dye was well described by a pseudosecond-order model. Based on the results obtained from thermodynamic parameters, such as enthalpy change $\left(\Delta \mathrm{H}^{\circ}\right)$, entropy change $\left(\Delta \mathrm{S}^{\circ}\right)$, and changes in the Gibbs free energy $\left(\Delta \mathrm{G}^{\circ}\right)$, it was revealed that the adsorption process was exothermic, physisorption, feasible, and spontaneous.

\section{Acknowledgments}

The authors wish to thank Yazd Branch, Islamic Azad University and Qaemshahr Branch, Islamic Azad University for support of the project.

\section{Conflict of interest}

The Authors have no conflict of interest.

\section{Reference}

1. Zareyee D, Tayebi $\mathrm{H}$, and Javadi SH. Preparation of polyaniline/activated carbon composite for removal of reactive red 198 from aqueous solution. Iranian Journal of Organic Chemistry 2012; 4(1): 799-802. DOI:4 1799802

2. Gan Y, Tian Na, Tian X, Ma L, Wang W, Yang $\mathrm{C}$, Zhou $\mathrm{Zh}$, and Wang $\mathrm{Y}$. Adsorption behavior of methylene blue on amine-functionalized ordered mesoporous alumina. J Porous Mater 2015; 22: $147-$ 155. DOI: 10.1007/s10934-014-9881-9

3. Anbia M, Salehi S. 2012; Removal of acid dyes from aqueous media by adsorption onto amino-functionalized nanoporous silica SBA-3. Dyes and Pigments 2012; 94 : 1-9.

http://doi.org/10.1016/j.dyepig.2011.10.016

4. Qin Q, Ma J, and Liu K. Adsorption of anionic dyes on ammonium-functionalized MCM-41. Journal of Hazardous Materials 2009; 162: 133-139.http://doi. org/10. 1016/j.jhazmat.2008.05.016 
5. Muthukumar M, Sargunamani D, Selvakumar N, Rao JV. Optimisatio of ozone treatment for colour and COD removal of acid dye effluent using central composite design experiment. Dyes and Pigments 2004; 63: 127-134. http://doi.org/10.1016/j.dyepig.2004.02.003

6. Shi B, Li G, Wang D, Feng C, Tang H. Removal of direct dyes by coagulation: The performance of preformed polymeric aluminum species. Journal of Hazardous Materials 2007; 143: 567-574. http:// doi.org/10.1016/j.jhazmat.2006.09.076

7. Riera-Torres M, Gutiérrez-Bouzán C, Crespi M. Combination of coagulationflocculation and nanofiltration techniques for dye removal and water reuse in textile effluents. Desalination 2010; 252: 53-59. http://doi.org/10.1016/j.desal.2009.11.002

8. Gupta VK, Jain R, Nayak A, Agarwal Sh, Shrivastava M. Re moval of the hazardous dye-Tartrazine by photodegradation on titanium dioxide surface. Materials Science and Engineering C 2011; 31: 1062-1067. http://doi.org/10.1016/j.msec.2011.03.006

9. Yang CH, Lee CC, Wen TC. Hypochlorite generation on Ru-Pt binary oxide for treatment of dye wastewater. Journal of Applied Electrochemistry 2000; 30: 10431051. DOI: 10.1023/A:1004038503410

10. Kornaros M, Lyberatos G. Biological treatment of wastewaters from a dye manufacturing company using a trickling filter. Journal of Hazardous Materials 2006; 136: 95-102. http://doi. org/10. 1016/ j.jhazmat.2005.11.018

11. Chu HC, Chen KM. Reuse of activated sludge biomass: I. Removal of basic dyes from wastewater by biomass. Process Biochemistry 2002; 37: 595-600. http://doi.org/10.1016/S00329592(01)00234-5

12. Zhu M, Lee L, Wang H, Wang Z. Removal of an anionic dye by adsorption/ precipitation processes using alkaline white mud. Journal of Hazardous Materials 2007; 149: 735-741. http://doi.org/ 10.1016/j .jhazmat.2007.04.037

13. Ai L, Zhou Y, Jiang J. Removal of methylene blue from aqueous solution by montmorillonite $/ \mathrm{CoFe}_{2} \mathrm{O}_{4}$ composite with magnetic separation performance. Desalination 2011; 266: 72-77. http:// doi. org/10.1016/j.desal.2010.08.004
14. Daneshvar N, Khataee AR, Rasoulifard MH, Pourhassan M. Biodegradation of dye solution containing Malachite Green: Optimization of effective parameters using Taguchi method. Journal of Hazardous Materials 2007; 143: 214-219. http://doi. org/10.1016/j.jhazmat.2006.09.016

15. Sponza DT, Isik M. Decolorization and azo dye degradation by anaerobic/aerobic sequential process. Enzyme and Microbial Technology 2002; 31 : $102-$ 110.http://doi.org/10.1016/S0141-0229 (02) 00081-9

16. Shu H, Huang $C$, and Chang $M$. Decolorization of mono-azo dyes in wastewater by advanced oxidation process: A case study of acid red 1 and acid yellow 23. Chemosphere 1994; 29(12): 2597-2607. https://doi.org/10.1016/0045-6535 90060-4

17. Vlyssides AG, Papaioannou D, Loizidoy M, Karlis PK, Zorpas AA. Testing an electrochemical method for treatment of textile dye wastewater. Waste Management 2000; 20: 569-574. http://doi. org/10.1016/S0956-053X(00) 00028-3

18. Shukla P, Wang S, Sun H, Ang H, Tadé M. Adsorption and heterogeneous advanced oxidation of phenolic contaminants using Fe loaded mesoporous SBA-15 and $\mathrm{H}_{2} \mathrm{O}_{2}$. Chemical Engineering Journal 2010; 164: 255-260. http://doi.org/10.1016/j.cej.2010.08.061

19. Biglari H, Javan N, Khosravi R, Zarei A. Direct Blue 71 Removal from Aqueous Solutions by Adsorption on Pistachio Hull Waste: Equilibrium, Kinetic and Thermodynamic Studies.Iranian Journal of Health Sciences 2016; 4(2): 55-70. DOI: 10.18869/acadpub.jhs.4.2.55

20. Sobhanardakani S, Zandipak R. Removal of Anionic Dyes (Direct Blue 106 and Acid Green 25) from Aqueous Solutions Using Oxidized Multi-Walled Carbon Nanotubes. Iranian Journal of Health Sciences 2015; 3(3): 48-57. DOI: 10.7508/ijhs.2015.03.006

21. Zazouli M A, Balarak D, Mahdavi Y, Ebrahimi M. Adsorption rate of 198 reactive red dye from aqueous solutions by using activated red mud. Iranian journal of health sciences 2013; 1(1): 36-43. DOI: 10.18869/acadpub.jhs.1.1.36

22. Thu P, Dieu H, Phi H, Viet N, Kim S, Vo V. Synthesis, characterization and phenol 
adsorption of carbonyl-functionalized mesoporous silicas. J Porous Mater 2012; 19: 295-300. DOI: 10.1007/s10934-0119475-8

23. Kao H, Liao C, Palani A, Liao Y. One-pot synthesis of ordered and stable cubic mesoporous silica SBA-1 functionalized with amino functional groups. Microporous and Mesoporous Materials 2008; 113: 212 223. http://doi. org/10.1016/j. micromeso. 2007.11.030

24. Anbia M, Hariri S. Removal of methylene blue from aqueous solution using nanoporous SBA-3. Desalination 2010; 261: 61-66. http://doi.org/10.1016/j.desal.2010.05.030

25. Da'na E, Sayari A. Adsorption of heavy metals on amine-functionalized SBA-15 prepared by co-condensation: Applications to real water samples. Desalination 2012; 285: 62-67. http://doi.org/10.1016/j. desal. 2011.09.034

26. Kleitz F, Czuryszkiewicz T, Solovyov L, and Lindén M. X-ray Structural Modeling and Gas Adsorption Analysis of Cagelike SBA-16 Silica Mesophases Prepared in a F127/Butanol $/ \mathrm{H}_{2} \mathrm{O}$ System. Chem. Mater 2006; 18 (21): 5070-5079. DOI: 10.1021/ $\mathrm{cm} 061534 \mathrm{n}$

27. Lee C, Liu S, Juang L, Wang C, Lin K, Lyu M. Application of MCM-41 for dyes removal from wastewater. Journal of Hazardous Materials 2007; 147: 997-1005. http://doi.org/10.1016/j.jhazmat.2007.01.13 0

28. De la Iglesia O, Pedernera M, Mallada R, Linc Z, Rocha J, Coronas J, Santamaria J. Synthesis and characterization of MCM-48 tubular membranes. Journal of Membrane Science 2006; 280: 867-875. doi:10.1016/j. memsci.2006.03.016

29. Punyapalakul P, Takizawa S. Selective adsorption of nonionic surfactant on hexagonal mesoporous silicates (HMSs) in the presence of ionic dyes. Water Research 2006; 40: 3177 - 3184. http://doi.org/ 10.1016/j.watres.2006.07.008

30. Zhao A, Samanta A, Sarkar P, and Gupta R. Carbon Dioxide Adsorption on AmineImpregnated Mesoporous SBA-15 Sorbents: Experimental and Kinetics Study. Ind. Eng. Chem. Res 2013; 52(19): 64806491. doi:10.1016/j.watres.2006.07.008

31. Kamarudin KSN, Alias N. Adsorption performance of MCM-41 impregnated with amine for $\mathrm{CO}_{2}$ removal." Fuel Processing Technology 2013; $106: 332-$ 337.http://doi.org/ 10.1016/j .fuproc. 2012. 08.017

32. Gil M, Tiscornia I, de la Iglesia O, Mallada R, Santamaria J. Monoamine-grafted MCM-48: An efficient material for $\mathrm{CO} 2$ removal at low partial pressures. Chemical Engineering Journal 2011; 175: 291- 297. http://doi.org/10.1016/j.cej.2011.09.107

33. Sanz R, Calleja G, Arencibia A, SanzPe'rez ES. $\mathrm{CO}_{2}$ adsorption on branched polyethyleneimine-impregnated

mesoporous silica SBA-15. Applied Surface Science 2010; 256: 5323-5328. http://doi.org/10.1016/j.apsusc.2009.12.070

34. Bhagiyalakshmi M, Yun L, Anuradha R, Jang $\mathrm{H}$. Utilization of rice husk ash as silica source for the synthesis of mesoporous silicas and their application to $\mathrm{CO}_{2}$ adsorption through TREN/TEPA grafting. Journal of Hazardous Materials 2010; 175: 928-938. http://doi.org/ 10.1016/j.jhazmat. 2009.10.097

35. Ballav N, Maity A, Mishra SB. High efficient removal of chromium (VI) using glycine doped polypyrrole adsorbent from aqueous solution. Chemical Engineering Journal 2012; 198-199: 536-546. http://doi.org/10.1016/j.cej.2012.05.110

36. Daraei P, Madaeni SS, Ghaemi N, Salehi E, Khadivi M, Moradian R, Astinchap B. Novel polyethersulfone nanocomposite membrane prepared by $\mathrm{PANI} / \mathrm{Fe}_{3} \mathrm{O}_{4}$ nanoparticles with enhanced performance for $\mathrm{Cu}$ (II) removal from water. Journal of Membrane Science 2012; 415-416: 250259. http://doi.org/10.1016/j.memsci. 2012. 05.007

37. Ansari R, and Mosayebzadeh Z. Removal of Basic Dye Methylene Blue from Aqueous Solutions Using Sawdust and Sawdust Coated with Polypyrrole. J. Iran. Chem. Soc. 2010; 7(2): 339-350. http:// www.sid.ir/En/VEWSSID/J_pdf/88320100 207.pdf.

38. Bhaumik M, Maity A, Srinivasu VV, Onyango MS. Removal of hexavalent chromium from aqueous solution using polypyrrole-polyaniline nanofibers. Chemical Engineering Journal 2012; 181182: 323- 333. http://doi.org/ 10.1016/j. cej.2011.11.088 
39. Mansour MS, Ossman ME, Farag HA. Removal of Cd (II) ion from waste water by adsorption onto polyaniline coated on sawdust. Desalination 2011; 272: 301-305. http://doi.org/10.1016/j.desal.2011.01.037

40. Krishnani KK, Srinives S, Mohapatra BC, Bodd, VM, Hao J, Meng X, Mulchandani A. Hexavalent chromium removal mechanism using conducting polymers. Journal of Hazardous Materials 2013; 252 253: 99- 106 . http://doi.org/10. 1016/j. jhazmat.2013.01.079

41. Shafiabadi M, Dashti A, Tayebi H. Removal of $\mathrm{Hg}$ (II) from aqueous solution using polypyrrole/SBA-15 nanocomposite: Experimental and modeling. Synthetic Metals 2016; 212: 154-160. http://doi. org/10.1016/j.synthmet.2015.12.020

42. Tayebi H, Yazdanshenas M E, Rashidi A, Khajavi R, Montazer M. The Isotherms, Kinetics, and Thermodynamics of Acid Dye on Nylon6 with Different Amounts of Titania and Fiber Cross Sectional Shape. Journal of Engineered Fibers and Fabrics 2015; 10(1): 97-108.

43. Tayebi H, Dalirandeh Z, Shokuhirad A, Mirabi A, Binaeian E. Synthesis of polyaniline/Fe3O4 magnetic nanoparticles for removal of reactive red 198 from textile waste water: kinetic, isotherm, and thermodynamic studies. Desalination and Water Treatment 2016; 1-13. http://dx. doi.org/10.1080/19443994.2015.1133323

44. Bakala P, Briot E, Salles L, Bre'geault J. Comparison of liquid-phase olefin epoxidation over $\mathrm{MoO}_{\mathrm{x}}$ inserted within mesoporous silica (MCM-41, SBA-15) and grafted onto silica. Applied Catalysis A: General 2006; 300: 91-99. http://doi. org/10.1016/j.apcata.2005.09.038

45. Li Q, Yu H, Song J, Pan X, Liu J, Wang Y, Tang L. Synthesis of SBA-15/polyaniline mesoporous composite for removal of resorcinol from aqueous solution. Applied Surface Science 2014; 290: 260- 266. http://doi.org/10.1016/j.apsusc.2013.11.065

46. Katiyar A, Ji L, Smirniotis P, Pinto NG. Protein adsorption on the mesoporous molecular sieve silicate SBA-15: effects of $\mathrm{pH}$ and pore size. Journal of Chromatography A 2005; 1069: 119-126. http://doi.org/10.1016/j.chroma.2004.10.07 7
47. Ullah R, Atilhan M, Aparicio S, Canlier A, Yavuz CT. Insights of $\mathrm{CO}_{2}$ adsorption performance of amine impregnated mesoporous silica (SBA-15) at wide range pressure and temperature conditions. International Journal of Greenhouse Gas Control 2015; 43: 22-32. http://doi. org/10.1016/j.ijggc.2015.09.013

48. Bui T, Choi H. Adsorptive removal of selected pharmaceuticals by mesoporous silica SBA-15. Journal of Hazardous Materials 2009; 168: 602-608. http://doi. org/10.1016/j.jhazmat.2009.02.072

49. Yiu HHP, Wright PA, Botting NP. Enzyme immobilisation using SBA-15 mesoporous molecular sieves with functionalised surfaces." Journal of Molecular Catalysis B: Enzymatic 2001; 15: 81-92. http:// doi.org/10.1016/S1381-1177(01)00011-X

50. Mureseanu M, Reiss A, Stefanescu I, David E, Parvulescu V, Renard G, Hulea V. Modified SBA-15 mesoporous silica for heavy metal ions remediation. Chemosphere 2008; 73: 1499-1504. http:// doi.org/10. 1016/j.chemosphere. 2008.07.039

51. Wu C. Adsorption of reactive dye onto carbon nanotubes: Equilibrium, kinetics and thermodynamics. Journal of Hazardous Materials 2007; 144: 93-100.http:// doi. org/10.1016/j. jhazmat. 2006.09.083

52. Kumar PS, Ramalingam S, Senthamarai C, Niranjanaa M, Vijayalakshmi P, Sivanesan $\mathrm{S}$. Adsorption of dye from aqueous solution by cashew nut shell: Studies on equilibrium isotherm, kinetics and thermodynamics of interactions. Desalination 2010;261: 52-60. http://doi.org/10.1016/j.desal.2010.05.032

53. Indra DM, Vimal CS, Nitin KA. Removal of Orange-G and Methyl Violet dyes by adsorption onto bagasse fly ashdkinetic study and equilibrium isotherm analyses. Dyes and Pigmentsb2006; 69: 210-223. http://doi.org/10.1016/j.dyepig.2005.03.013

54. Peng X, Huang D, Odoom-Wubah T, Fu D, Huang J, Qin Q. Adsorption of anionic and cationic dyes on ferromagnetic ordered mesoporous carbon from aqueous solution: Equilibrium, thermodynamic and kinetics. Journal of Colloid and Interface Science 2014; 430: 272-282. http://doi. Org/10. 1016/ j.jcis.2014.05.035 